\title{
Quantification of stem cell factor mRNA levels in the rat testis: usefulness of clusterin mRNA as a marker of the amount of mRNA of sertoli cell origin in post pubertal rats
}

\author{
Ingrid Plotton, Pascale Sanchez, Marie Hélène Perrard, \\ Phillipe Durand and Hervé Lejeune
}

UMR INSERM 418/INRA 1245, Université Claude Bernard Lyon 1, Hôpital Debrousse, 69322 Lyon, France

(Requests for offprints should be addressed to H Lejeune, Département de Médecine de la Reproduction, Pavillon K1, Hôpital Edouard Herriot, Place d'Arsonval, 69437 Lyon Cedex 03, France; Email: herve.lejeune@chu-lyon.fr)

\begin{abstract}
Spermatogenesis is a complex cellular process regulated by gonadotrophins and local cell-cell interactions. Stem cell factor $(\mathrm{SCF})$ is one of the paracrine factors, produced by the Sertoli cells, involved in the local regulation of spermatogenesis. Measurement of its testicular level is important for addressing its role in testis physiopathology. However, the relative cell composition of experimental and pathological testis samples may lead to misinterpretation in relating SCF mRNA levels to the amount of RNA extracted from the whole tissue sample. Taking into account the relative RNA content of Sertoli cell origin should provide more significant data. In the present study, three sets of experiments were intended for modifying the proportion of RNA of Sertoli cell origin in RNA extracted from whole testis tissue samples: during postnatal development; following methoxy-acetic acid (MAA) administration; and after injecting a long-acting gonadotrophin-releasing hormone agonist (GnRHa). In a first step, we demonstrated clusterin mRNA level stability in purified Sertoli cell preparations between 20 days and adulthood, and following MAA or GnRHa treatment. In a second step, we used a competitive RT-PCR assay to
\end{abstract}

measure SCF and clusterin mRNA levels and expressed the amount of SCF mRNA relative to the amount of clusterin mRNA under the above experimental conditions. The SCF/clusterin mRNA level ratio was found to remain roughly stable from 20 days post-partum to adulthood; i.e. during the development of spermatogenesis. MAA administration led to an overall increase in the SCF/clusterin mRNA level ratio between 7 and 14 days after administration, consistent with the replenishment of the testis with pachytene spermatocytes and round spermatids. Conversely, after long-acting GnRHa injection, the SCF/clusterin mRNA level ratio decreased only slightly from day 21 onward. Hence, the present studies indicate that, under physiopathological conditions, the amount of clusterin mRNA is a good marker of the amount of RNA of Sertoli cell origin in testis samples at day 20 or later; different experimental alterations of spermatogenesis are associated with different patterns of SCF mRNA levels; the relationship between FSH and SCF in vivo is not as simple as that described in vitro.

Journal of Endocrinology (2005) 186, 131-143

\section{Introduction}

Spermatogenesis is a complex cellular process involving stem cell multiplication and differentiation, genome reorganisation during meiosis, and a very specific cytodifferentiation to produce highly specialised sperm cells. This process is regulated by gonadotrophins acting on Leydig and Sertoli cells, which regulate germ cell differentiation by local interactions (Parvinen 1982, Skinner 1991, Kierszenbaum 1994). The blood-testis barrier isolates the germ cells in a specific environment mainly controlled by the Sertoli cells. Sertoli cells produce several signalling molecules acting in a paracrine manner on the developing germ cells (Gnessi et al. 1997). The relative importance of the various paracrine factors in regulating the various steps of the spermatogenic process, the regulation of their production and their potential abnormalities in spermatogenic failure have not yet, however, been determined precisely. Measuring the production of these paracrine factors in experimental and pathological conditions is of importance in order to address some of these issues.

Stem cell factor (SCF) is one of these factors produced by the Sertoli cells (Rossi et al. 1991). It is involved in regulating spermatogonial proliferation (Rossi et al. 1993), but also in later stages of spermatogenesis (Vincent et al. 1998) and in reducing germ cell apoptosis (Yan et al. 2000). Like most paracrine factors, SCF mRNA has been 
quantified from RNA extracted from the whole testis (Rossi et al. 1993, Hakovirta et al. 1999, Yan et al. 1999, Goddard et al. 2001). However, the cellular heterogeneity of the testis and its variations in experimental and pathological samples may cause misinterpretation in relating data to the amount of RNA extracted from the whole tissue sample. Taking into account the relative content of RNA of Sertoli cell origin should provide more significant data.

Clusterin, also referred to, among other names, as sulphated glycoprotein 2 (Tenniswood et al. 1998), has been shown to be produced within the testis by the Sertoli cells (Morales et al. 1987), and clusterin mRNA levels have been shown to be unmodified by germ cells or gonadotrophins in Sertoli cell cultures (Hugly et al. 1988, Roberts et al. 1991, 1992). In order to measure accurately the mRNA levels of paracrine factors produced by the Sertoli cell, such as SCF, we sought to assess the use of the clusterin mRNA level as a marker of the amount of mRNA of Sertoli cell origin. Testicular tissue was obtained from three sets of experiments in rats, in which variations in the number and/or volume of somatic cells and/or germ cells have been described: (1) during postnatal development which is characterised by the dramatic growth and differentiation of the germ cell (Zhengwei et al. 1990) and interstital cell (Ariyaratne \& Chamindrani Mendis-Handagama 2000) populations, and the functional maturation of Sertoli cells - the number of which remains constant from about 15 days post-partum onward (Wang et al. 1989, Zhengwei et al. 1990); (2) following administration of methoxy-acetic acid (MAA), a toxin specific for spermatocytes which induces an acute spermatocyte depletion followed by a repopulation wave from spermatogonia ( $\mathrm{Li}$ et al. 1996) and modest rarefaction and slight vacuolisation of Sertoli cells (Chapin \& Lamb 1984); (3) after one injection of a long-acting gonadotrophinreleasing hormone agonist (GnRHa), which leads to down-regulation of gonadotrophin secretion inducing Sertoli cell functional alterations, but no change in their number, resulting in a progressive germ cell depletion (Pelletier et al. 1978, Rivier et al. 1979). These developmental or experimental modifications of the relative number/volume, differentiation status and function of the different testicular cell types were expected to change the proportion of RNA of Sertoli cell origin in RNA extracted from whole testis samples.

In a first step, we established that, from 20 days of age onward, and under both our experimental treatments of adult rats, clusterin mRNA levels remained stable in purified Sertoli cell preparations and conversely varied in whole testicular tissue samples. This suggested that clusterin mRNA may be used as a marker of the amount of RNA of Sertoli cell origin. Thus, in a second step, we used a competitive RT-PCR assay to measure SCF and clusterin mRNA under the above experimental conditions and expressed the amount of SCF mRNA relative to the amount of clusterin mRNA.

\section{Materials and Methods}

\section{Animals}

Sprague-Dawley rats were used throughout. They were maintained at $20^{\circ} \mathrm{C}$ in a fixed $12 \mathrm{~h}$ light: $12 \mathrm{~h}$ darkness cycle with free access to food and water. The experiments were conducted according to our institution's Guide of Care and Use of Laboratory Animals. All procedures were approved by the Scientific Research Agency (Approval No., 69306). Rats were killed by decapitation and their testes were rapidly removed.

\section{Developmental study}

Testes were obtained from 10-, 20-, 30-, 40-, 60- and 90-day-old rats.

\section{MAA treatment}

Testes were obtained 3, 7 and 14 days after a single i.p. injection of MAA $(650 \mathrm{mg} / \mathrm{kg}$ body weight) to adult (90-day old) rats. MAA (Sigma) was dissolved in sterile water and adjusted to $\mathrm{pH} 7 \cdot 0$ by $\mathrm{NaOH}$.

\section{GnRH agonist treatment}

Testes were obtained 2, 3 and 4 weeks after a single i.m. injection of $1.5 \mathrm{mg}$ of a long-acting preparation of D-Trp6GnRH (Decapeptyl; kindly provided by Ipsen Biotech, France) to adult (90-day-old) rats.

\section{Testicle histology}

After multipuncture of the albuginae, one testis was immersed in Bouin's solution in each experimental condition. The fixed testicular tissue was paraffin-embedded, cut at $5 \mu \mathrm{m}$ and stained with periodic acid Schiff (PAS).

\section{Isolation of Sertoli cells}

Since the number of Sertoli cells per testis was rather similar under the three experimental conditions tested (Pelletier et al. 1978, Rivier et al. 1979, Chapin \& Lamb 1984, Zhengwei et al. 1990), the number of testes used for Sertoli cell purification ranged between 20 and 30 in each experiment. Testes were decapsulated and collected in Ham's F-12/Dulbecco's modified Eagle's medium (F-12/ DMEM, 1:1) (Gibco) supplemented with $15 \mathrm{mM}$ Hepes, $\mathrm{NaHCO}_{3}(1.2 \mathrm{~g} / \mathrm{l})$ and containing $1 \mathrm{mg} / \mathrm{ml}$ collagenase (Serva Biowhittaker, Fontenay-sous-Bois, France), $5 \mu \mathrm{g} / \mathrm{ml}$ DNAse (Sigma) and $0.5 \mu \mathrm{g} / \mathrm{ml}$ soybean trypsine inhibitor (Sigma). Digestion was performed for $20 \mathrm{~min}$ at $34{ }^{\circ} \mathrm{C}$ under constant agitation. The seminiferous tubules were cut in small fragments, sedimented twice and further digested as above for $15 \mathrm{~min}$. The remaining fragments 
were sedimented again and further fragmented by passing slowly through a 19-gauge syringe needle. This led to disruption of the tubular structures allowing the progressive removal of germ cells out of the tubule fragments. These fragmentation-sedimentation cycles were repeated until the number of isolated germ cells was reduced to a low value (see below); for adult rats, because of the high number of germ cells in testes, five to eight fragmentation-sedimentation cycles were necessary instead of the two to three used for young animals.

\section{Immunocytochemistry}

Vimentin immunoreactivity was used to determine the percentage of germ cells (vimentin-negative) contaminating the (vimentin-positive) Sertoli cell preparations (Oke \& Suarez-Quian 1993). An aliquot of each Sertoli cell preparation was cytospun onto aminoalkylsilanised slides. The cells were fixed in Bouin's solution, and rinsed twice with ethanol $(70 \%)$ then once with $\mathrm{NaCl} 0.9 \%$. Cell membranes were permeabilised with $0.03 \%$ Triton $\mathrm{X}-100$. An anti-vimentin specific monoclonal antibody (Dako, France) was used at a dilution of 1:1000. Vimentin immunoreactivity was revealed by a biotin-coupled goat anti-mouse antibody incubated with streptavidinecoupled horseradish peroxidase (Dako) giving a brown coloration to the Sertoli cells after reaction with diaminobenzidine. The cell nuclei were then stained with haematoxylin. The percentage of vimentin-negative cells in the Sertoli cell preparations was (mean \pm S.D) $9 \cdot 6 \pm 2 \cdot 5 \%$ $(n=27)$ in adult rats with no variation in either GnRHaor MAA-treated animals; it was $7 \cdot 3 \pm 1 \cdot 5,11 \cdot 0 \pm 2 \cdot 2$, $8 \cdot 8 \pm 1 \cdot 8,8 \cdot 9 \pm 1 \cdot 8$ and $8 \cdot 2 \pm 1 \cdot 6 \%$ in $10-, 20-, 30-, 40-$ and 60-day-old rats respectively ( $n=3$ for each age).

Vimentin immunoreactivity was also used to identify and count Sertoli cells in histological sections. Since the number and/or volume of Sertoli cells, germ cells and intertitial cells may vary according to the above physiological and experimental conditions (Zhengwei et al. 1990, Ariyaratne \& Chamindrani Mendis-Handagama 2000), the variations in the proportion of Sertolian tissue in the testis were roughly estimated by calculating the ratio of the number of Sertoli cells to the total number of cells counted on randomly chosen histological sections. In each experimental condition, at least 2000 cells were counted in randomly chosen microscopic fields at $\times 1000$ magnification. The cells were classified according to the following criteria: Sertoli cells (vimentin-positive cells within the seminiferous tubule), germ cells (vimentin-negative cells within the seminiferous tubule) and interstitial cells (vimentin-positive cells outside the tubules).

\section{RNA extraction}

Total RNA was extracted following a modification of Chomczynski and Sacchi's method (Chomczynski \&
Sacchi 1987) as previously described (Xie \& Rothblum 1991). Small pieces of freshly removed testicular tissue were disrupted in the RNA extraction solution with a polytron at $0{ }^{\circ} \mathrm{C}$.

\section{Northern blot analysis}

An RT-PCR-synthesised cDNA corresponding to nucleotides 798-1145 of the published sequence (Wong et al. 1993) (accession no. NM_053021) was used as a template for synthesis of the rat clusterin probe, labelled to a specific activity of $10^{9}$ d.p.m. per microgram DNA with $\left[\alpha_{-}{ }^{32} \mathrm{P}\right] \mathrm{dCTP}$ by the random priming method (Megaprime DNA labelling kit, Amersham).

Total RNA was denatured by heating $\left(95^{\circ} \mathrm{C}\right.$ for $\left.2 \mathrm{~min}\right)$ and resolved by electrophoresis (5 $\mathrm{g} /$ lane) through $1 \%$ agarose gel containing $10 \%$ formaldehyde, then transferred onto a Hybond-N nylon membrane (Amersham). RNAs were cross-linked to the membranes by irradiation for 2 min with u.v. light and baking at $80{ }^{\circ} \mathrm{C}$ for $2 \mathrm{~h}$. Prehybridisation was performed for at least $2 \mathrm{~h}$ at $42^{\circ} \mathrm{C}$ in $50 \%$ formamide, SSPE $\left(0.75 \mathrm{M} \mathrm{NaCl}, 20 \mathrm{mM} \mathrm{NaPO}_{4}\right.$, $\mathrm{pH} 7.5$ and $1 \mathrm{mM}$ EDTA), $5 \times$ Denhardt's solution $(0 \cdot 1 \%$ Ficoll $400,0 \cdot 1 \%$ polyvinylpyrolidone and $0 \cdot 1 \%$ BSA), $0 \cdot 1 \%$ SDS, $10 \%$ dextran sulphate and $100 \mathrm{mg} / \mathrm{ml}$ denatured salmon sperm DNA. Hybridisation was carried out overnight at $42{ }^{\circ} \mathrm{C}$ in the same buffer, containing $10^{6}$ d.p.m. per millilitre ${ }^{32} \mathrm{P}$-labelled rat clusterin probe. The nylon membranes were washed as follows: twice in $2 \times$ SSC $(1 \times$ SSC: $150 \mathrm{mM} \mathrm{NaCl}, 15 \mathrm{mM}$ sodium citrate, $\mathrm{pH} 7 \cdot 4), 0 \cdot 1 \%$ SDS at room temperature for $15 \mathrm{~min}$ each; then twice in $1 \times \mathrm{SSC}, 0 \cdot 1 \% \operatorname{SDS}$ at $65^{\circ} \mathrm{C}$ for $15 \mathrm{~min}$ each; once in $0.5 \times \mathrm{SSC}, 0.1 \% \mathrm{SDS}$ at $65^{\circ} \mathrm{C}$ for $15 \mathrm{~min}$; and in $0 \cdot 1 \times \mathrm{SSC}, 0 \cdot 1 \% \mathrm{SDS}$ at $65^{\circ} \mathrm{C}$ for $5 \mathrm{~min}$. Autoradiograms were obtained after a $12 \mathrm{~h}$ exposure at $-70{ }^{\circ} \mathrm{C}$ to Hyperfilm M P (Amersham) with intensifying screens.

Thereafter, membranes were stripped by washing three times in water at $90{ }^{\circ} \mathrm{C}$ and once in $1 \%$ SDS in water at $90^{\circ} \mathrm{C}$, and hybridised as above with a synthetic oligonucleotide probe specific for $28 \mathrm{~S}$ ribosomal RNA, labelled with T4 kinase and $\left[\gamma_{-}{ }^{32} \mathrm{P}\right]$ ATP to a specific activity of $10^{9}$ d.p.m. per microgram (Barbu \& Dautry 1989). The nylon membranes were washed as above and autoradiograms were obtained after $2 \mathrm{~h}$ exposure at $-70{ }^{\circ} \mathrm{C}$ to Hyperfilm M.P. (Amersham) with intensifying screens.

Autoradiograms were subjected to densitometry scanning and analysed with the NIH-IMAGE software. The data from the Northern blots were then expressed as clusterin signal/28S signal.

\section{Competitive RT-PCR}

This method is based upon the use of a synthetic RNA competitor which allows the monitoring of both reverse 

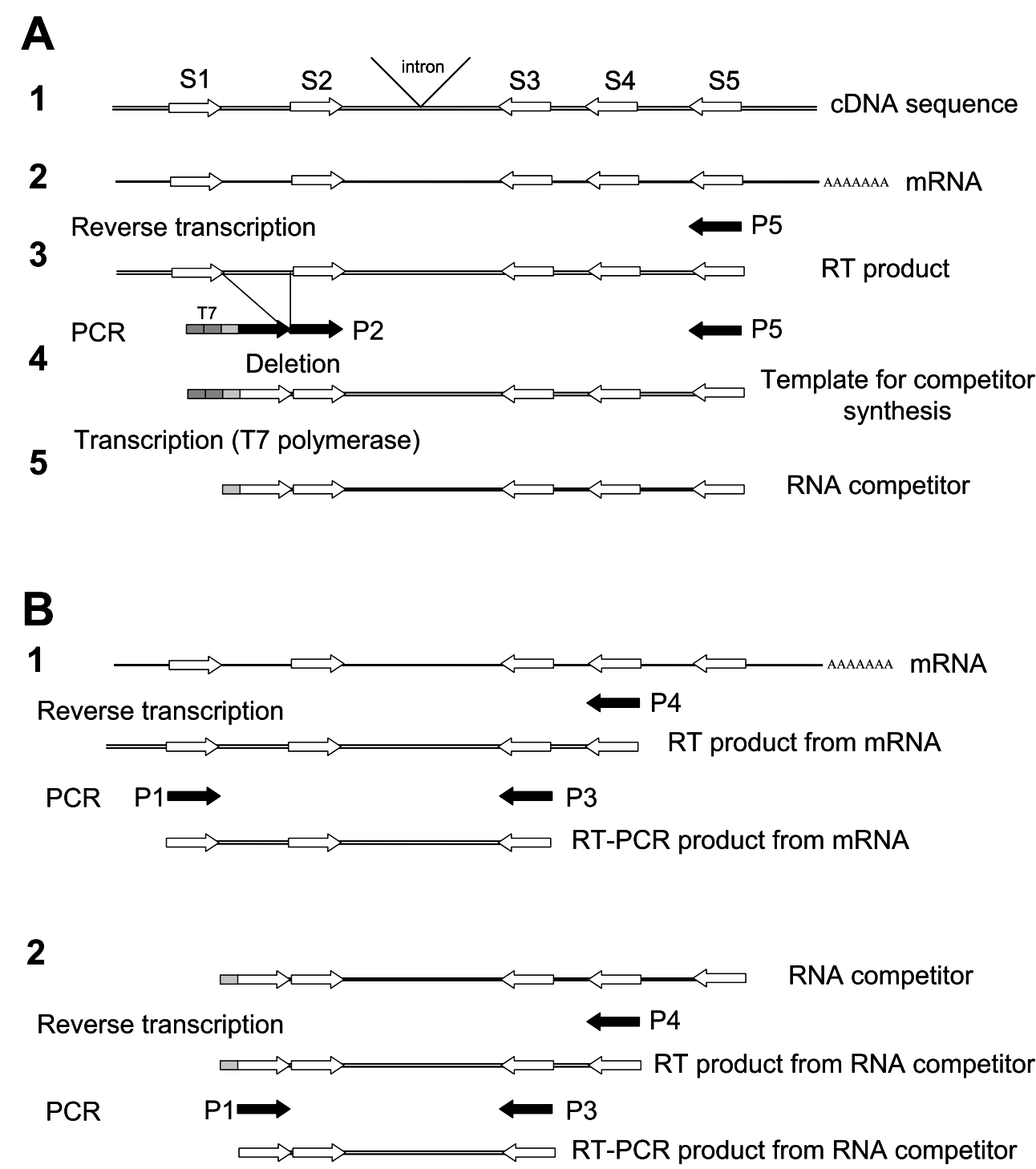

Figure 1 Schematic representation of RNA competitor synthesis and competitive RT-PCR. (A) RNA competitor synthesis. (1) Location of the sequences used for competitor synthesis and the competitive RT-PCR: S1, sequence used for the forward primer of the competitive PCR (P1); S2, sequence used to create a deletion for the competitor synthesis; S3, sequence for the reverse primer of the competitive PCR; S4, sequence for the reverse primer of the reverse transcription for the competitive PCR; S5, sequence for the reverse primer of the reverse transcription for the synthesis of the competitor. (2) mRNA with the sequences S1-S5. (3) Reverse transcription from the mRNA for the synthesis of the template for the RNA competitor synthesis (P5 primer). (4) Synthesis of the template for the RNA competitor synthesis by PCR (P2 and P5 primers). (5) In vitro transcription with modified nucleotides form the CDNA template giving the RNA competitor. (B) Competitive RT-PCR; in the same tube, reverse transcription (P4 primer) and then PCR (P1 and P3 primers) were run in parallel from both the mRNA to be measured (1) and a known amount of RNA competitor (2).

transcription and PCRs. The stability of this RNA is increased by incorporating modified nucleotides, making the competitor RNA resistant to ribonuclease.

Competitor synthesis and quantification The construction of competitor RNAs with modified nucleotides was performed with the Ambion RT-PCR competitor construction kit (catalogue no. 1356) according to the manufacturer's instructions.

Figure 1 shows the principles of RNA competitor synthesis (Fig. 1A) and of competitive RT-PCR (Fig. 1B). The corresponding sequences, spanning different exons, 
Table 1 Nucleotide sequences used for construction of RNA competitors, competitive RT-PCR and determination of the molecular forms of SCF mRNA. The position of the first and the last nucleotide is given relative to the start codon $(+1)$ following the cDNA seqeunces

\begin{tabular}{|c|c|c|}
\hline \multicolumn{3}{|c|}{ rClusterin (Wong et al. 1993) (accession no. NM_053021) } \\
\hline S1 & $+798 ;+817$ & 5'-ACAGTTCCCGGATGTGGATT-3' \\
\hline S2 & $+893 ;+912$ & 5'-AGGGCCAGTGTGAGAAGTGC-3' \\
\hline S3 & $+1126 ;+1145$ & 5'-CAGGGCGATGACCAGTACCT-3' \\
\hline S4 & $+1203 ;+1232$ & 5'-TGAGGTGGTGGTGAAGCTGTTTGACTCTGA-3' \\
\hline S5 & $+1285 ;+1304$ & 5'-ATGGACACAGTGGCAGAGAA-3' \\
\hline \multicolumn{3}{|c|}{ rSCF (Martin et al. 1990) (accession no. NM_021843) } \\
\hline S1 & $-4 ;+21$ & 5'-CCTTATGAAGAAGACACAAACTTGG-3' \\
\hline S2 & $+129 ;+148$ & 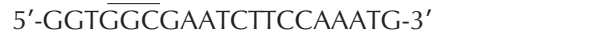 \\
\hline S3 & $+402 ;+425$ & 5'-СТTТАСТССТGAAGAATTCTTTAG-3' \\
\hline S4 & $+440 ;+459$ & 5'-CСАTTGATGCСТTCAAGGAC-3' \\
\hline S5 & $+500 ;+520$ & 5'-CAACATTAGGTCCTGAGAAAG-3' \\
\hline \multicolumn{3}{|c|}{ rSCF mRNA molecular forms } \\
\hline RT & $+766 ;+790$ & 5'-GAGGATAATGAGATAAGTATGTTGC-3' \\
\hline Forward & $+275 ;+297$ & 5'-CTGAAGGCTTGAGTAATTATTCC-3' \\
\hline Reverse & $+691 ;+714$ & 5'-GCTTTTGGAGCCTTATACTGGAAG-3' \\
\hline
\end{tabular}

were chosen according to the published rat clusterin (Wong et al. 1993; accession no. NM_053021) and rat SCF (Martin et al. 1990; accession no. NM_021843) cDNA sequences and are given in Table 1. Sequence 1 (S1) was the sequence for the forward primer for the PCR (P1, see Fig. 1B). Sequence 2 (S2), located downstream of $\mathrm{S} 1$, was used to construct the primer used for preparing the cDNA template for RNA competitor synthesis (P2). P2 included successively: the $\mathrm{T} 7$ polymerase promoting sequences, followed by a sequence of ten nucleotides including only $\mathrm{G}$ and A (5'-GGGAGAGGAG-3'), allowing the beginning of the in vitro translation without the incorporation of modified nucleotides ( $\mathrm{c}$ and $\mathrm{u}$ ), followed by S1, followed by S2. The succession of S1-S2 induced a deletion between these two sequences. The deletion was of $75 \mathrm{bp}$ for rClusterin and $107 \mathrm{bp}$ for rSCF. Sequence 3 (S3), located in a downstream exon, was used for the reverse primer of the PCR (P3, see Fig. 1B). Sequence 4 (S4) was used for the reverse primer of the reverse transcription (P4, see Fig. 1B). Sequence 5 (S5) was used for the reverse primer used for the competitor template synthesis (P5).

Competitve RT-PCR As shown schematically in Fig. 1B, single strand cDNAs were synthesised by reverse transcription using the same primer (P4) from the mRNA to be quantified and from the competitor RNA added in a known amount in the same tube. The reverse transcription was performed for $1 \mathrm{~h}$ at $37^{\circ} \mathrm{C}$, in a volume of $20 \mu \mathrm{l} /$ tube: 200 units Moloney murine leukemia reverse transcriptase (Life Technologies), $10 \mathrm{mM}$ dithiothreitol (DTT), $1.25 \mathrm{mM}$ of each dNTP, $0.3 \mu \mathrm{l}$ RNAsine,
15 pmol P4 primer, $0 \cdot 1 \mu \mathrm{g}$ total RNA and the following amounts of RNA competitor: $1 \times 10^{6}, 2 \times 10^{6}, 5 \times 10^{6}$, $1 \times 10^{7}, 2 \times 10^{7}$ and $5 \times 10^{7}$ copies for rClusterin; $2 \times 10^{4}$, $5 \times 10^{4}, 1 \times 10^{5}, 2 \times 10^{5}, 5 \times 10^{5}$ and $1 \times 10^{6}$ copies for rSCF.

Two microlitres of reverse transcription products were subjected to PCR in a volume of $100 \mu \mathrm{l} /$ tube containing 50 pmol P1 primer, 50 pmol P3 primer and $0.25 \mathrm{mM}$ of each dNTP. After a denaturation step $\left(5 \mathrm{~min}\right.$ at $\left.94{ }^{\circ} \mathrm{C}\right), 2$ units/tube of Taq polymerase (Roche) were added while the temperature was maintained at $80^{\circ} \mathrm{C}$. The PCR was then performed for 40 cycles: $94^{\circ} \mathrm{C}$ for $1 \mathrm{~min}, 55^{\circ} \mathrm{C}$ for $2 \mathrm{~min}$ and $72{ }^{\circ} \mathrm{C}$ for $1 \mathrm{~min}$. The RT-PCR products obtained from the mRNA and from the synthetic RNA competitors were respectively 348 and $273 \mathrm{bp}$ for rClusterin and 429 and $322 \mathrm{bp}$ for rSCF. They were resolved with $1.5 \%$ agarose gel electrophoresis in the presence of ethidium bromide. Photographs of ethidium bromide u.v. fluorescence of the RT-PCR product bands were subjected to densitometry scanning and analysed with NIH-IMAGE software. The ratio of the RT-PCR products from the mRNA to the RT-PCR products from the competitor RNA was calculated and plotted against the initial competitor RNA concentration on a bi-logarithmic scale. The regression line was calculated and the initial concentration of mRNA was determined as the competitor concentration corresponding to ratio $=1$ (Fig. 2).

The intra- and inter-assay coefficients of variation were respectively $14 \cdot 4$ and $29 \cdot 3 \%$ for clusterin $\mathrm{mRNA}$ and $17 \cdot 7$ and $34.7 \%$ for SCF mRNA as determined by repeated measurements (both $n=12$ ) of the same RNA sample. 

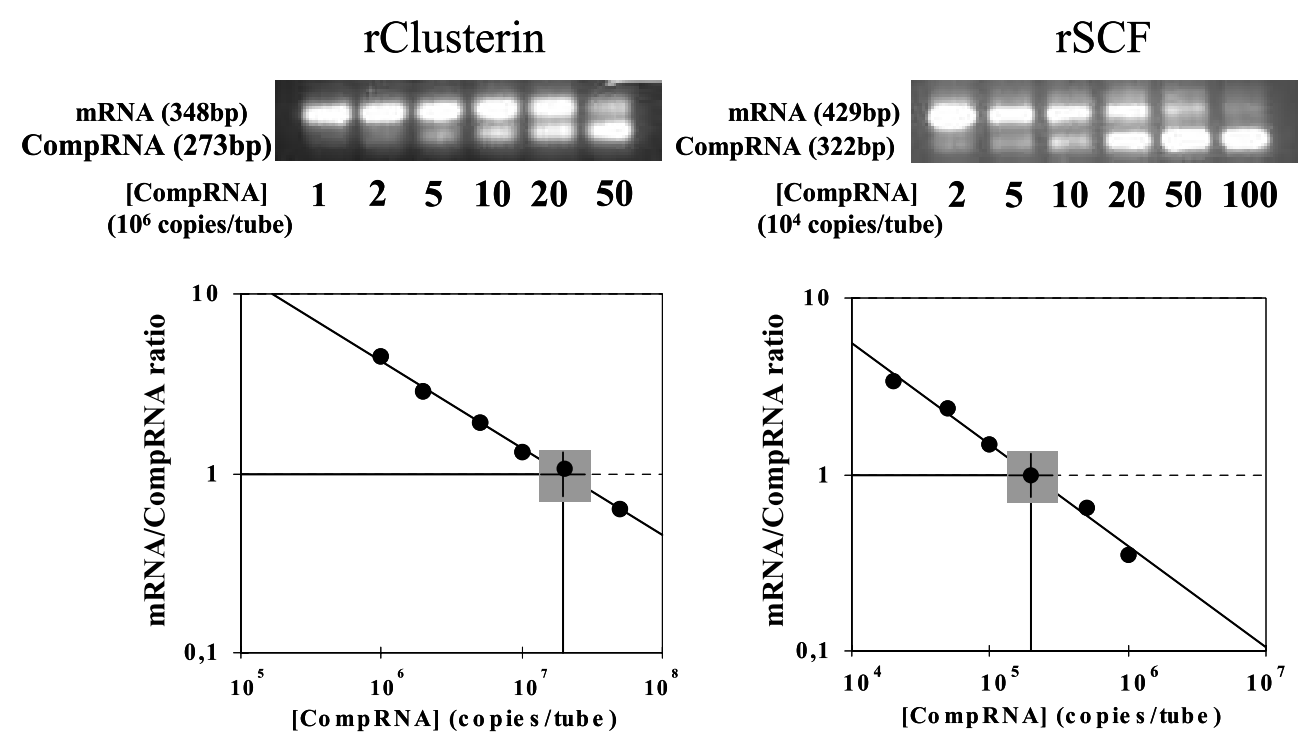

Figure 2 A typical quantification of rClusterin mRNA and rSCF mRNA by competitive RT-PCR with RNA competitor. Upper panels, photographs of ethidium bromide u.v. fluorescence of the RT-PCR products resolved by agarose gel electrophoresis: rClusterin mRNA (348 bp), deleted rClusterin synthetic RNA competitor (273 bp), rSCF mRNA (429 bp) and deleted rSCF synthetic RNA competitor (322 bp). Lower panels, plots of the mRNA to RNA competitor ratio in relation to the RNA competitor concentration.

Determination of the molecular forms of stem cell factor $m R N A$

Both the membrane-bound and the soluble forms of SCF are produced by the Sertoli cells (Marziali et al. 1993). The mRNA of the soluble form is characterised by the presence of exon 6, which codes for a proteolytic site involved in the release of the extracellular C-terminal part of the molecule (Flanagan et al. 1991). It can be distinguished from the mRNA of the membrane-bound SCF, which is characterised by a skipped exon 6 , and by the smaller size of the RT-PCR products obtained with primers located on either side of exon 6 . The primer for reverse transcription was chosen from the nucleotide sequence +766 ; +790 (exon 8 ), the forward primer for PCR, from the nucleotide sequence $+275 ;+297$ (exon 4) and the reverse primer for PCR, from the nucleotide sequence $+691 ;+714$ (exon 7) (Table 1). The RT-PCR products were of 356 and $440 \mathrm{~kb}$ for the membranebound and the soluble forms of SCF respectively.

The PCR products were resolved with 1.5\% agarose gel electrophoresis in the presence of ethidium bromide. Photographs of ethidium bromide u.v. fluorescence of the RT-PCR product bands were subjected to densitometry scanning and analysed with NIH-IMAGE software. The ratio of membrane-bound SCF mRNA to soluble SCF mRNA was estimated from the ratio of the RTPCR products.

\section{Statistical analysis}

The results of clusterin and SCF mRNA quantification were compared between groups by ANOVA followed by
Fisher's PLSD test, after logarithmic transformation if required to equalise variance. $P<0.05$ was considered significant. Unless otherwise indicated, values are means \pm S.E.M of three independent experiments.

\section{Results}

Validation of clusterin $m R N A$ level as a stable marker of the $R N A$ of Sertoli cell origin

The results of the measurement of clusterin mRNA levels relative to 28S RNA by Northern blot analysis of RNA extracted from purified Sertoli cell preparations or from whole testicle samples are shown in Figs 3A, 5A and 7A for the developmental study, the MAA treatment and the GnRHa treatment respectively; Figs 3B, 5B and 7B give the corresponding ratios of the number of Sertoli cells to the total number of cells counted in histological sections.

During post-natal development, the timing of the appearance of the germ cells was concordant with the description given by Clermont and Perrey (1957) and Marret et al. (1998). Briefly, the most advanced germ cells were spermatogonia at 10 days, spermatocytes at 20 days, round spermatids at 30 days, elongated spermatids at 40 days and spermatozoa at 60 days. The number of germ cells increases dramatically during the development of spermatogenesis (Zhengwei et al. 1990) while the Sertoli cells stop dividing at about 15 days post-partum (Wang et al. 1989, Zhengwei et al. 1990). In parallel, the volume of the Sertoli cells is altered during the first wave of spermatogenesis (Zhengwei et al. 1990). Lastly, both the number and volume of interstitial cells increase between 


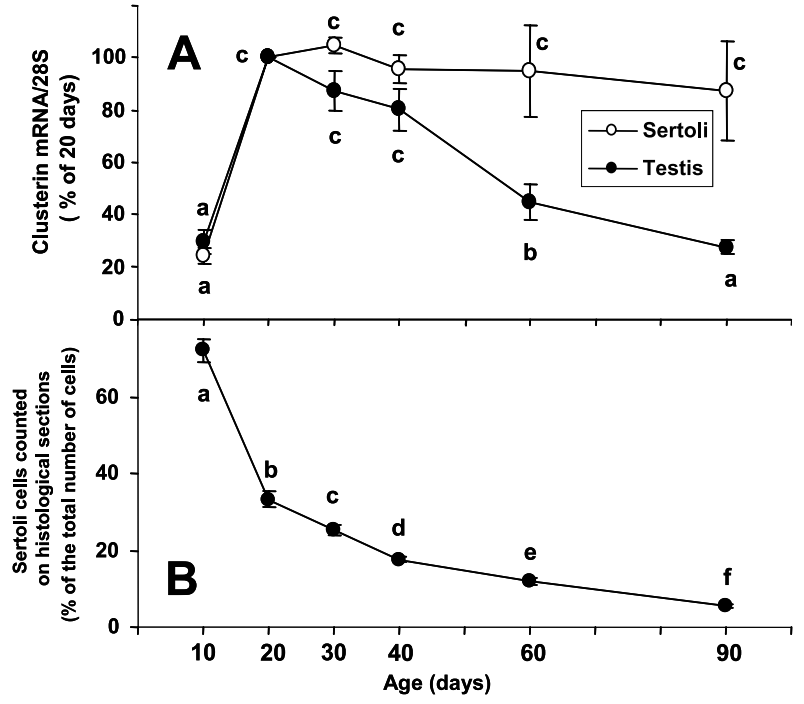

Figure 3 Post-natal developmental study. (A) changes in clusterin mRNA levels, measured by Northern blot, in RNA extracted from either whole testes $(-)$ or Sertoli cell preparations $(\bigcirc)$ of rats at different days of life. Each point is the mean \pm S.E.M. of 3 experiments. (B) Changes in the percentage of Sertoli cells counted on randomly chosen histological sections of rat testes (see Materials and Methods) on different days of life. Each point is the mean \pm S.E.M. of 20-40 randomly chosen microscopic fields. In both panels, values with different superscripts are significantly different.

birth and 90 days (Ariyaratne \& Chamindrani MendisHandagama 2000). These changes were reflected by an age-related decrease $(P<0.0001)$ in the ratio of the number of Sertoli cells to the total number of cells counted on randomly chosen histological sections (Fig. 3B) (see Materials and Methods section).

Clusterin mRNA levels (Fig. 3A) were low at 10 days of age and increased 4 -fold by 20 days in RNA extracted from both whole testicle samples $(P<0 \cdot 0001)$ and purified Sertoli cell preparations $(P<0 \cdot 0001)$. Thereafter, the clusterin mRNA levels remained stable in RNA extracted from purified Sertoli cell preparations, but decreased 4 -fold $(P<0 \cdot 0002)$ in whole testicle samples.

The histological features of rat testes following MAA administration were concordant with previous descriptions (Foster et al. 1987, Bartlett et al. 1988, Li et al. 1996). Degeneration of pachytene spermatocytes was observed on day 3; degeneration of late spermatocytes and round spermatids associated with regeneration of pachytene spermatocytes appeared on day 7; and degeneration of elongated spermatids associated with regeneration of spermatocytes and round spermatids was seen on day 14 (Fig. 4). Consequently, the ratio of the number of Sertoli cells to the total number of cells counted on histological sections increased about 2 -fold $(P<0 \cdot 0001)$ after MAA treatment to a plateau between days 7 and 14 (Fig. 5B). The clusterin mRNA levels (Fig. 5A) were unchanged in purified Sertoli cell preparations but increased $(P=0 \cdot 028)$ from day 3 onward in RNA from whole testicle samples.

The testicular weight decreased significantly $(P<0.0001)$ from $1.73 \pm 0.02 \mathrm{~g}$ (mean \pm S.E.M) before GnRHa injection to $1.55 \pm 0.02,1.46 \pm 0.04$ and $1.33 \pm$ $0.03 \mathrm{~g}$ at 2,3 and 4 weeks respectively after administration of the long-acting preparation of D-Trp6-GnRH to adult rats. An overall reduction in the number of germ cells was observed 2, 3 and 4 weeks after GnRHa administration (Fig. 6), as expected (Pelletier et al. 1978, Rivier et al. 1979). At the dose used in this work, germ cell degeneration was partial: some elongated spermatids were still present at each time point studied. In parallel, the ratio of the number of Sertoli cells to the total number of cells counted on histological sections increased from day 14 onward $(P<0 \cdot 0001)$ after GnRHa treatment (Fig. 7B). Clusterin mRNA levels (Fig. 7A) remained stable in purified Sertoli cell preparations but increased steadily $(P<0 \cdot 0001)$ with time in whole testis samples.

\section{Measurements of SCF and clusterin $m R N A$ levels by competitive RT-PCR}

In order to measure SCF and clusterin mRNA from small amounts of tissue, such as can be obtained from co-cultures of Sertoli and germ cells (Weiss et al. 1997), seminiferous tubule cultures (Staub et al. 2000) or testicular biopsies, we developed a competitive RT-PCR procedure that monitored both the reverse transcription and the PCR steps.

The levels of SCF and clusterin mRNA measured in whole testis samples are given in panels A and B of Figs 8, 9 and 10 for developmental study, MAA treatment and GnRHa treatment respectively. The ratio of SCF mRNA levels to clusterin mRNA levels is given in the corresponding panel C.

During post-natal development, SCF mRNA levels decreased $(P=0 \cdot 0008)$ progressively with age from $7 \cdot 3 \pm$ $2.6 \times 10^{6}$ copies $/ \mu \mathrm{g}$ at 10 days, down to $0 \cdot 25 \pm 0 \cdot 08 \times$ $10^{6}$ copies/ $\mu \mathrm{g}$ at 90 days (Fig. 8A). In agreement with Northern blot analysis (Fig. 3A, O), clusterin mRNA levels measured by RT-PCR were low $\left(41 \pm 12 \times 10^{6}\right.$ copies $/ \mu \mathrm{g})$ at 10 days of age, increased 6 -fold $(P<0 \cdot 0001)$ at 20 days and decreased $(P=0 \cdot 0077)$ progressively thereafter down to $60 \pm 4 \times 10^{6}$ copies $/ \mu \mathrm{g}$ at 90 days (Fig. $8 \mathrm{~B}$ ). Because of the low value of clusterin mRNA levels at 10 days, the SCF mRNA/clusterin mRNA ratio was dramatically high on this day $\left(176 \pm 35 \times 10^{-3}\right)$. Thereafter, the SCF mRNA/clusterin mRNA ratio tended to decrease slightly but not significantly $(P=0 \cdot 15)$ between 20 and 90 days, to $4 \cdot 2 \pm 1 \cdot 3 \times 10^{-3}$ (Fig. 8C).

Following MAA administration, SCF mRNA levels increased $(P<0.0001) 7$-fold up to $1 \cdot 10 \pm 0.03 \times 10^{6}$

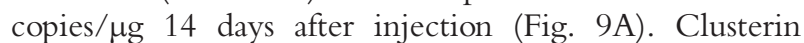
mRNA levels increased $(P=0 \cdot 0069)$ from $52 \pm 15 \times 10^{6}$ copies/ $\mu \mathrm{g}$ to a maximum value of $691 \pm 329 \times 10^{6}$ 

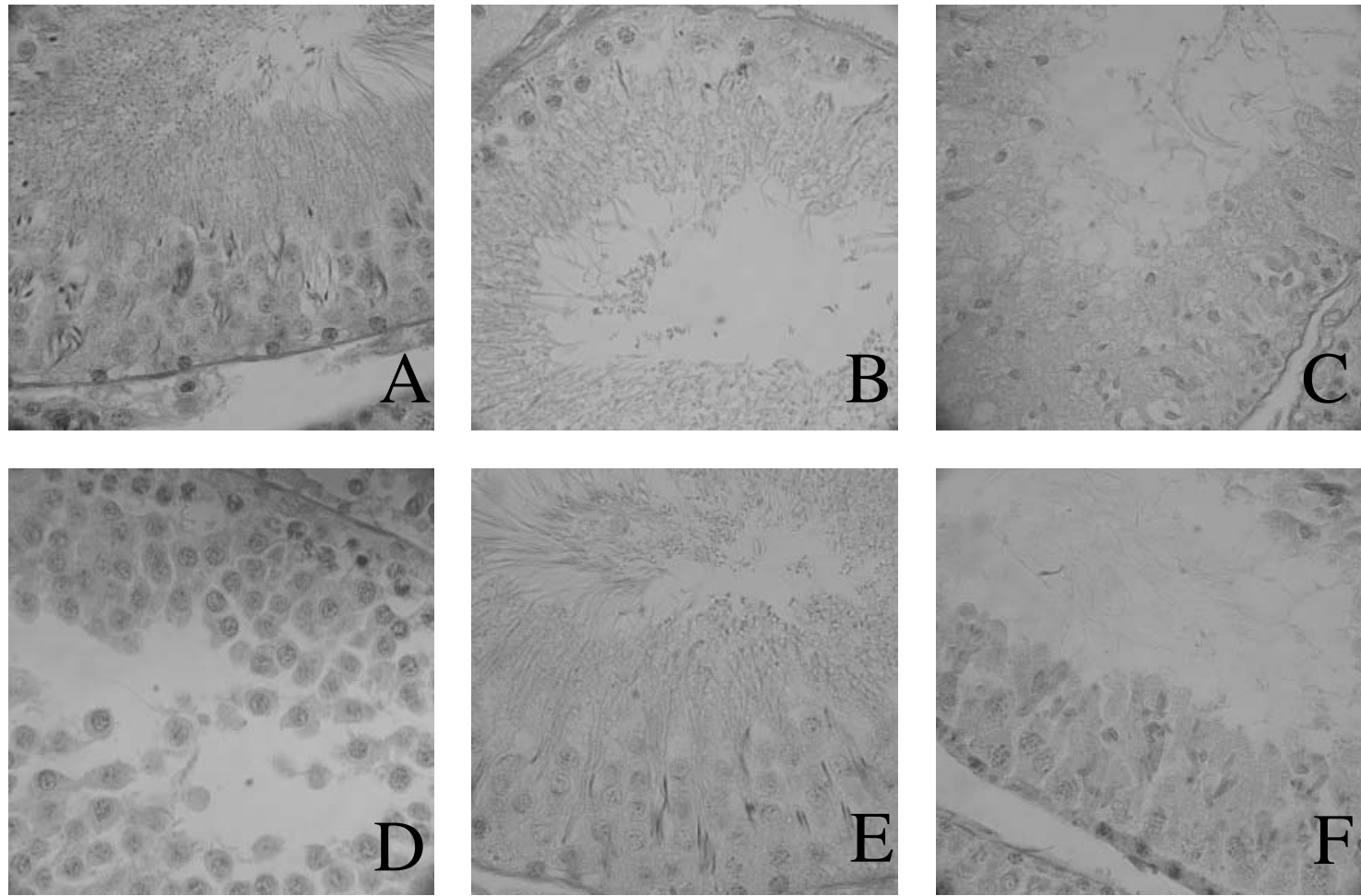

Figure 4 Histological alterations of rat spermatogenesis following MAA administration. Cross-sections of seminiferous epithelium show: (A) after 3 days, the absence of early pachytene spermatocytes (ePS) (stage V); (B) after 7 days, the lack of round spermatids (RS) associated with regeneration of ePS (stage I-II); (C) after 7 days, degeneration of late PS (IPS) (stage X); (D) after 14 days, absence of elongated spermatids (eS) while ePS and RS are present (stage III-IV); (E) stage III-IV in a control rat testis; $(F)$ stage $X$ in a control rat testis. Magnification $\times 250$.

copies/ $\mu \mathrm{g}$ on day 7 and returned on day 14 to a value not different from control levels (Fig. 9B). The SCF mRNA/ clusterin mRNA ratio remained stable until day 7 $\left(2 \cdot 7 \pm 0 \cdot 5 \times 10^{-3}\right)$, then increased 3.7-fold $(P=0 \cdot 0153)$ on day 14 (Fig. 9C).

After GnRHa treatment, SCF mRNA levels exhibited a biphasic pattern: a 5-fold increase between day 0 $\left(0 \cdot 18 \pm 0.02 \times 10^{6}\right.$ copies $\left./ \mu \mathrm{g}\right)$ and day 21 , then a decrease between days 21 and 28 down to $0.58 \pm 0.06 \times 10^{6}$ copies $/ \mu \mathrm{g}(P=0 \cdot 0014)$ (Fig. 10A). Clusterin mRNA levels increased 8-fold $(P=0 \cdot 0004)$, from $67 \pm 17 \times 10^{6}$ copies, over the 4 weeks after GnRHa injection (Fig. 10B). The SCF mRNA/clusterin mRNA ratio (Fig. 10C) was stable at $2 \cdot 6 \pm 0 \cdot 2 \times 10^{-3}$ until day 21 then decreased $(P=0 \cdot 0047) 2 \cdot 5$-fold at day 28 after treatment.

\section{Molecular forms of SCF $m R N A$}

The average percentage of the membrane-associated form of SCF mRNA was $52 \cdot 2 \pm 1 \cdot 4 \%(n=42)$ and remained unchanged during post-natal development $(P>0 \cdot 73)$, after MAA $(P>0.89)$ or after GnRHa administration $(P>0.99)$ (data not shown).

\section{Discussion}

Only extreme non-physiological conditions, such as a temperature of $43^{\circ} \mathrm{C}$, have been shown to alter the clusterin mRNA content of Sertoli cells in primary culture (Clark \& Griswold 1997). Thus, it seemed that clusterin mRNA might be a valuable candidate as a marker of the amount of mRNA of Sertoli cell origin (Maguire et al. 1997). However, it was necessary to assess the stability of clusterin mRNA in situations that could be encountered in vivo in pathological or experimental cases. In the present work, the stability of clusterin mRNA levels in Sertoli cells was directly investigated by measuring them in purified rat Sertoli cell preparations in a set of situations characterised by dramatic or mild variations in the relative number and/or volume of somatic cells and/or germ cells; i.e. post-natal development, and MAA or GnRHa treatment.

It was found that the only situation studied in which the clusterin mRNA level in Sertoli cells varied was at 10 days post-partum. In contrast, clusterin mRNA levels varied greatly in the corresponding whole testicle extracts. However, these latter variations were rather parallel to the variations in the proportion of Sertolian tissue in the testes 


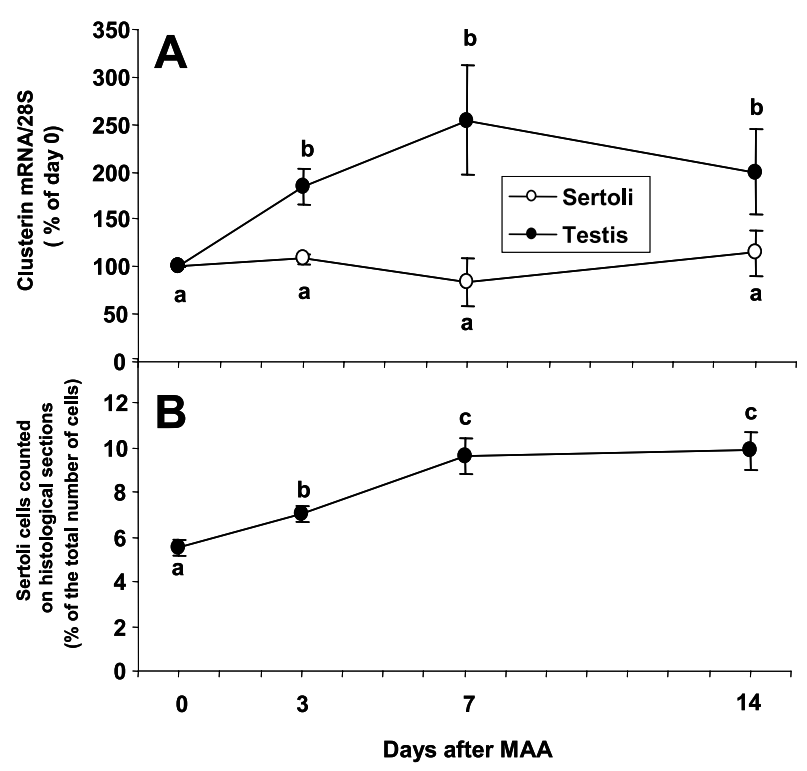

Figure 5 Effect of MAA administration to adult rats. (A) Changes in clusterin mRNA levels, measured by Northern bot, in RNA extracted from either whole testes $(\mathbf{O})$ or Sertoli cell preparations $(\bigcirc)$ of rats at different days after a single injection of MAA on day 0 . Each point is the mean \pm S.E.M. of 3 experiments. (B) Changes in the percentage of Sertoli cells counted on randomly chosen histological sections of rat testes on different days following a single injection of MAA on day 0. Each point is the mean \pm S.E.M. of 20-40 randomly chosen microscopic fields. In both panels, values with different superscripts are significantly different.

as estimated by the ratio of the number of Sertoli cells to the total number of cells counted on histological sections. These data indicated that the variations in clusterin mRNA level in the whole testicle samples were mainly, if not solely, due to the changes in their relative content in Sertolian tissue.

It must be underlined, that the ratio of the number of Sertoli cells to the total number of cells counted on

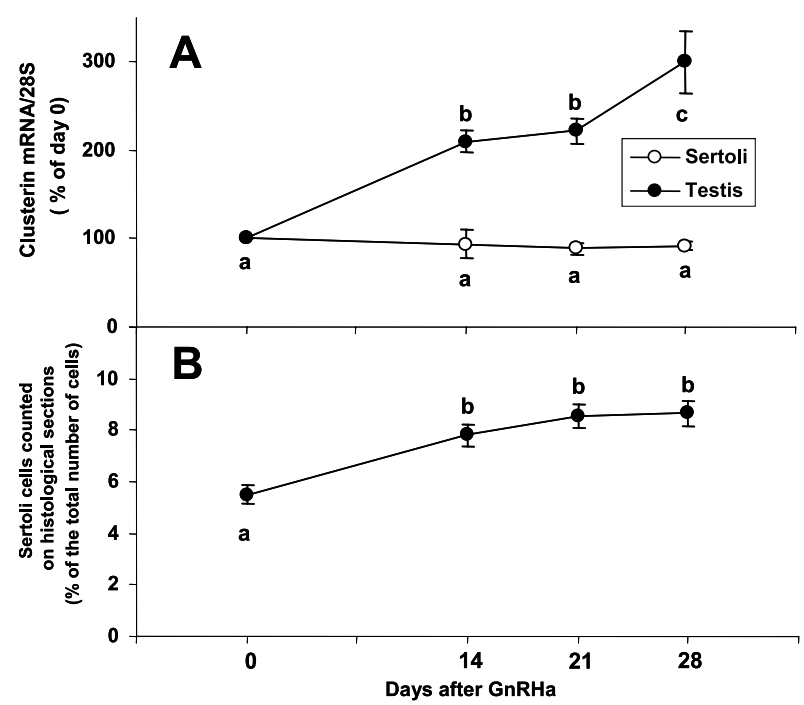

Figure 7 Effect of GnRHa administration to adult rats. (A) Changes in clusterin mRNA levels, measured by Northern blot, in RNA extracted from either whole testes $(\bullet)$ or Sertoli cell preparations (O) of rats at different days after a single injection of GnRHa on day 0 . Each point is the mean \pm S.E.M. of 3 experiments.

(B) Changes in the percentage of Sertoli cells counted on randomly chosen histological sections of rat testes on different days following a single injection of GnRHa on day 0. Each point is the mean \pm S.E.M. of 20-40 randomly chosen microscopic fields. In both panels, values with different superscripts are significantly different.

histological sections was in no way aiming to be an estimation of the number of Sertoli cells in the testis; this requires much more sophisticated methodologies to be determined (Wreford 1995). However, the ratio provides evidence that the proportion of Sertolian tissue in testis samples may vary greatly according to the different experimental/pathological conditions, even when the number of Sertoli cells remains unchanged.
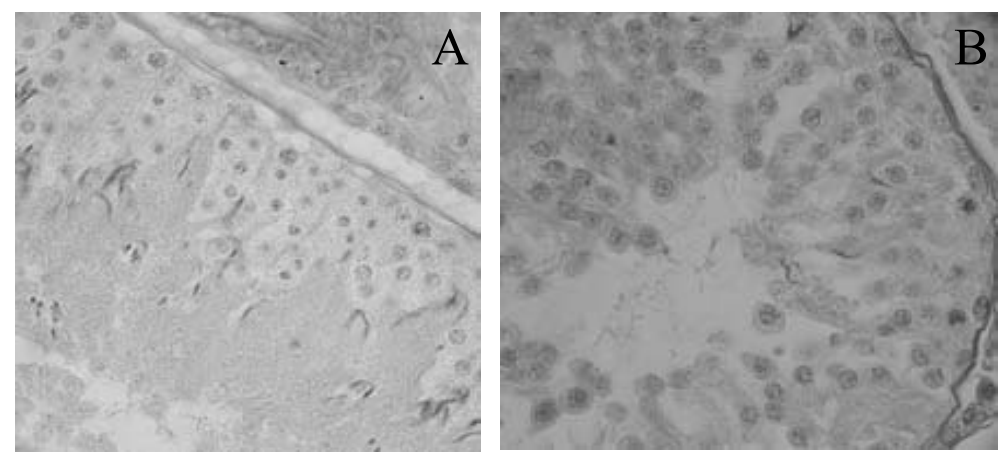

Figure 6 Histological alterations of rat spermatogenesis 4 weeks after a single injection of GnRHa. Cross-sections of seminiferous epithelium show: (A) lack of spermatogonia, abnormal round spermatids, in a stage I-II; (B) reduced number of pachytene spermatocytes $\mathrm{S}$ and very few elongated spermatids in a stage III-IV. For controls, see Fig. 4E and F. Magnification $\times 250$. 


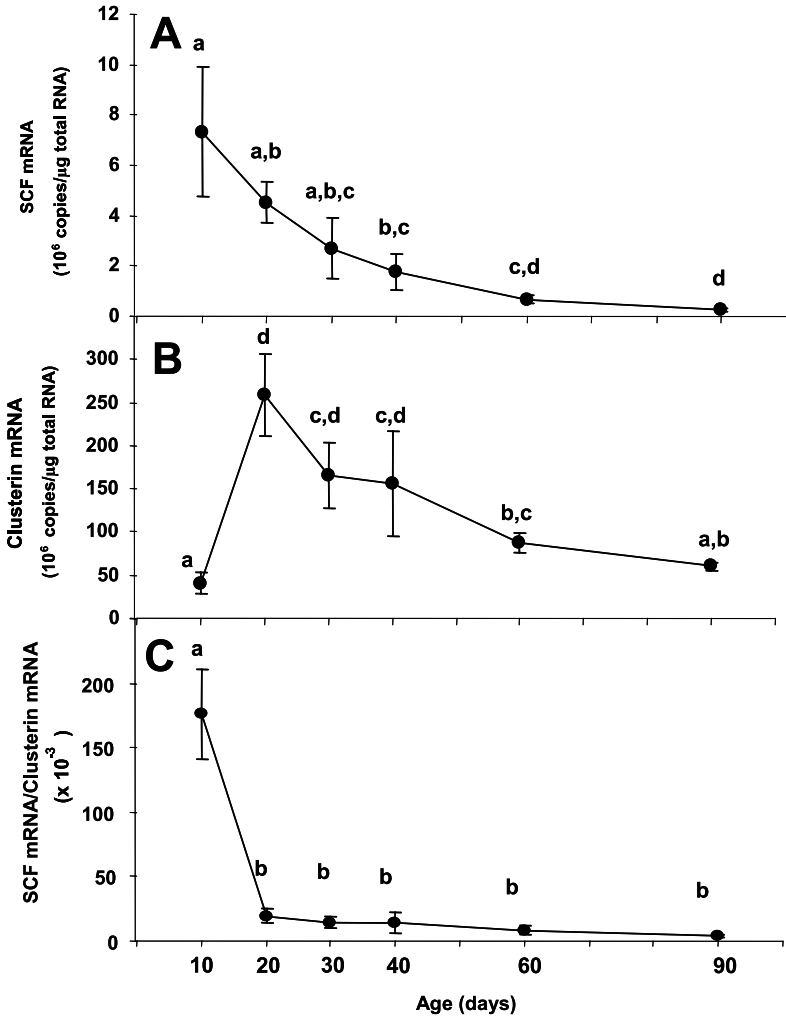

Figure 8 Changes in the levels of (A) SCF mRNA and (B) clusterin mRNA determined by competitive RT-PCR; (C) the SCF $\mathrm{mRNA} /$ clusterin mRNA ratio in whole rat testes on different days of post-natal life. Each point is the mean \pm S.E.M. of three experiments. In each panel, values with different superscripts are significantly different.

Similar variations were observed whether clusterin mRNA level was measured by Northern blot analysis or by competitive RT-PCR with RNA competitors; the latter method is much more sensitive than the former, enabling analysis from small amounts of tissue such as from clinical biopsies or Sertoli/germ cell co-cultures (Weiss et al. 1997, Staub et al. 2000). The use of clusterin mRNA as a marker of the amount of RNA of Sertoli cell origin is, however, limited to rats of 20 days old or more, since immature Sertoli cells do not express clusterin mRNA levels as high as those of mature Sertoli cells.

In the present study, SCF mRNA levels, measured by competitive RT-PCR in whole testicle samples, decreased during the development of spermatogenesis, as previously found by other authors (Hakovirta et al. 1999). In contrast, they increased following administration of MAA and followed a biphasic pattern after $\mathrm{GnRHa}$ administration to adult rats. These changes were, however, the expected result of the variations in the relative amount of Sertolian tissue in the samples on the one hand, and the variations in the SCF mRNA contents of the Sertoli cells on the other. Therefore, once clusterin mRNA level had been validated

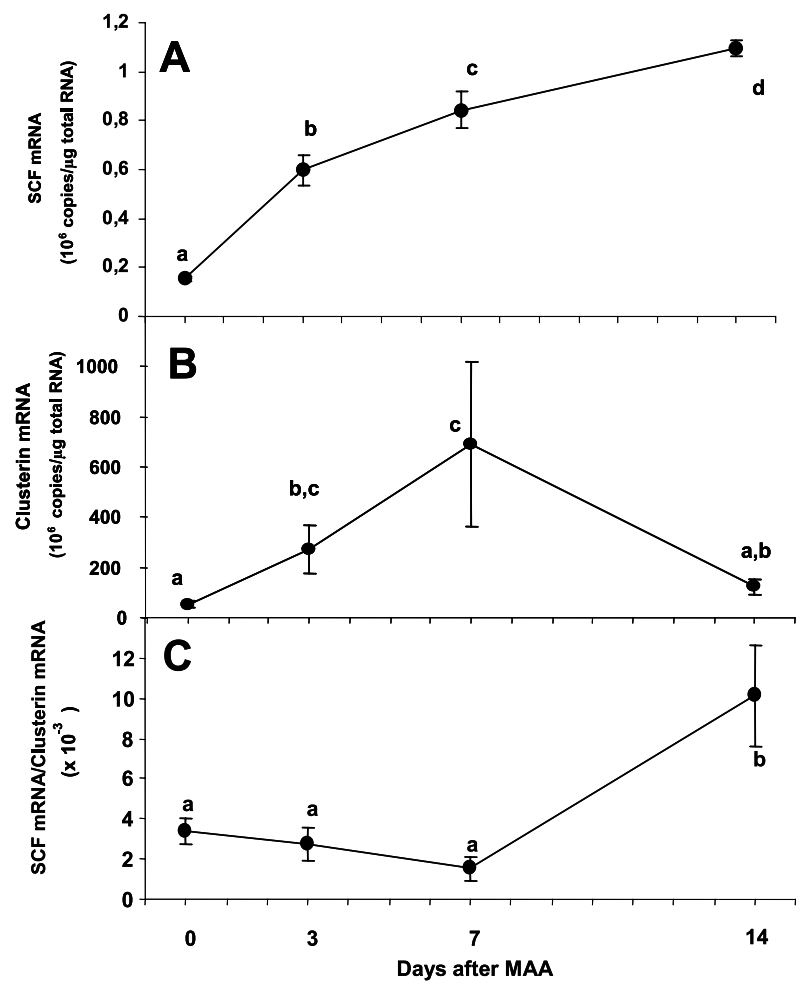

Figure 9 Changes in the levels of (A) SCF mRNA and (B) clusterin mRNA determined by competitive RT-PCR; (C) the SCF mRNA/clusterin mRNA ratio in whole rat testes on different days following a single injection of MAA on day 0 . Each point is the mean \pm S.E.M. of three experiments. In each panel, values with different superscripts are significantly different.

as a marker of the proportion of RNA of Sertoli cell origin beyond 20 days of age, we expressed the SCF mRNA level relative to the clusterin mRNA level. This should represent the true variation in the expression of SCF by Sertoli cells.

It was thus found that, in the rat, SCF mRNA levels remained roughly stable from 20 days post-partum to adulthood. Hakovirta et al. (1999) suggested that the decrease in SCF mRNA levels observed during post-natal development might be due to dilution by RNA of germ cell origin; the present data clearly confirm this hypothesis. Furthermore, constant SCF expression during the establishment and maintenance of spermatogenesis fits quite well with the fundamental role played by stem cell factor at several steps of spermatogenesis (see Sette et al. 2000 for review). More importantly, the present studies made it possible, for the first time, to quantify the 'physiological level' of SCF in the testis by measuring the Sertoli cell level of its mRNA. Indeed, for SCF, as for the other local regulatory molecules of spermatogenesis, no data are as yet available at the protein level. Hence, using quantitative RT-PCR to measure the level of an mRNA coding for a paracrine factor, in parallel with that of an mRNA coding 


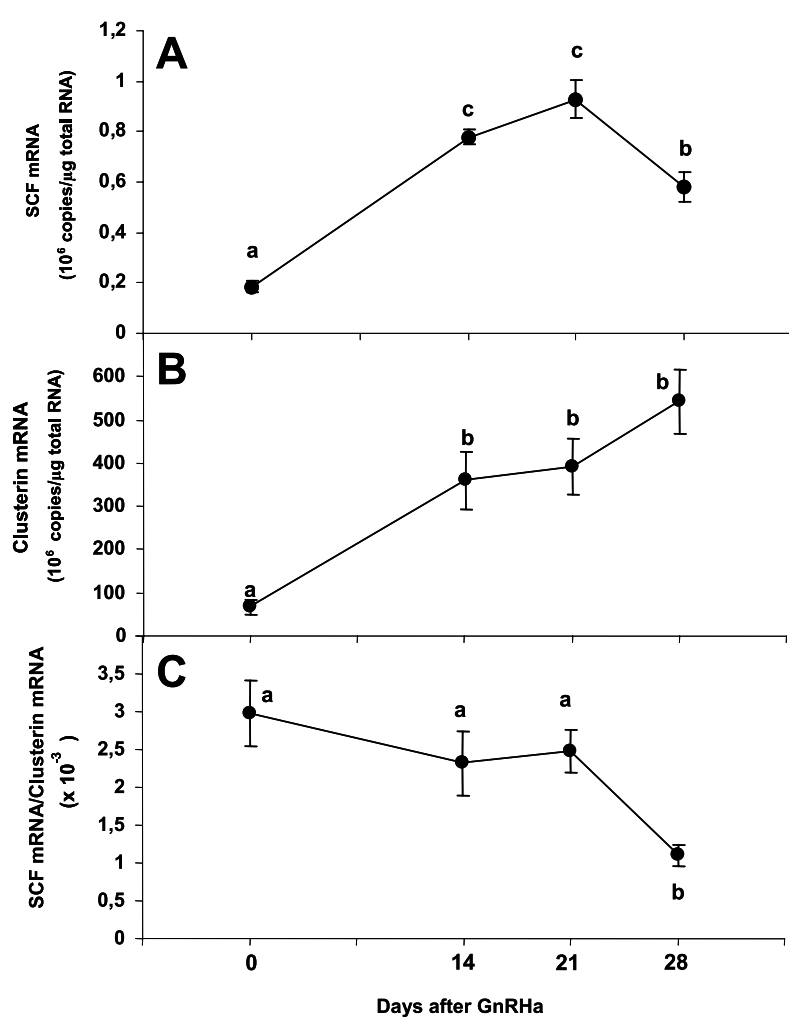

Figure 10 Changes in the levels of (A) SCF mRNA and (B) clusterin mRNA determined by competitive RT-PCR; (C) the SCF mRNA/clusterin mRNA ratio in whole rat testes on different days following a single injection of $\mathrm{GnRHa}$ on day 0 . Each point is the mean \pm S.E.M. of three experiments. In each panel, values with different superscripts are significantly different.

for a molecule constitutively expressed by the cells producing the factor, should enable the 'physiological level' of many intra-testicular paracrine factors to be determined. Such a strategy should be particularly useful for physiopathological studies.

MAA administration led to the sequential disappearance of certain categories of germ cell, followed by replenishment of the seminiferous tubules by the next spermatogenic wave from day 7 onward. During the first week following treatment, there was no decrease in the SCF/ clusterin mRNA level ratio. It has been suggested that germ cell apoptosis in response to MAA is a direct response to toxicant insult to Sertoli cells and may entail regulation of both pro-survival and pro-apoptotic factors (Boekelheide et al. 2000). If so, it seems rather unlikely that SCF is involved in such a response. Moreover, these studies indicated that lowering the number of germ cells supported by the Sertoli cells only marginally influenced the expression of SCF mRNA. This matches the results of the above 'corollary' developmental study showing that SCF mRNA levels were not significantly influenced by the progressive appearance of the various categories of germ cell between days 20 and 90 . Likewise, no change in these levels was observed during the first 3 weeks after GnRHa injection, despite a general reduction in the number of germ cells. Taken together, these results indicate that, in vivo, germ cells probably do not regulate SCF production by the Sertoli cells greatly, if at all.

An intriguing result of the present studies was the $3 \cdot 7$-fold increase in the SCF/clusterin mRNA level ratio which occurred between 7 and 14 days following MAA injection. No consistent effects on SCF mRNA expression in the seminiferous epithelium were found after testosterone or œstradiol stimulation (Yan et al. 1999). Likewise, there was no effect of transforming growth factor (TGF) $\beta$, TGF $\alpha$, tumour necrosis factor (TNF) $\alpha$ or activin on SCF gene expression. To date, the most widely recognised positive and negative regulators of SCF expression by Sertoli cells in vitro are follicle-stimulating hormone (FSH; Goddard et al. 2001, Rossi et al. 1993, Yan et al. 1999) and somatotrophin-release inhibitory factor (SRIF; Goddard et al. 2001) respectively, which act through the cAMP/ protein kinase A (PKA) pathway. Earlier studies showed that serum levels of FSH increase significantly within $24 \mathrm{~h}$ of treatment with MAA and increase further at 3 days, but return to control levels by day 7 . Luteinising hormone (LH) and testosterone levels do not change at any time after treatment (Bartlett et al. 1988). Therefore, it appears that the observed regeneration of pachytene spermatocytes and round spermatids between 7 and 14 days following MAA treatment is related more to increasing expression of Sertoli cell SCF than to any other putative regulatory factor studied so far.

Long-acting GnRH agonists first induce short-term stimulation of gonadotrophin secretion, followed by a sustained gonadotroph desensitisation, leading to low plasma gonadotrophin levels and decreased spermatogenesis. As expected, in the present study testis weight decreased and spermatogenesis was altered 14, 21 and 28 days after GnRHa administration. However, there was no decrease in the SCF/clusterin mRNA level ratio until between 3 and 4 weeks after injection. This late decrease in SCF mRNA level may be related to the progressive degenerative necrosis usually observed in Sertoli cells following GnRHa treatment (Pelletier et al. 1978, van Kroonenburgh et al. 1986). If so, this further confirms the robustness of clusterin as a marker of Sertoli cells in rat testis samples.

Both the increase in SCF mRNA level 14 days after MAA injection and the decrease 28 days after GnRHa treatment were late as compared with the plasma FSH increase 3 days after MAA and the FSH decrease 14 days after GnRHa previously reported (van Kroonenburgh et al. 1986, Bartlett et al. 1988). Taken together, these results indicate that there may not be as simple a relationship in vivo between FSH level and SCF gene expression as found in some in vitro systems (Rossi et al. 1993, Yan et al. 1999, Goddard et al. 2001). 
In summary, the present studies indicate that, under the above physiopathological conditions: (1) the measurement of mRNA coding for Sertoli cell derived SCF needs to be related to the amount of an mRNA constitutively expressed by the Sertoli cells; (2) the clusterin mRNA level is a good marker of the proportion of Sertolian tissue in testis samples at day 20 or later; (3) different experimental alterations of spermatogenesis are associated with different patterns of SCF mRNA level; and (4) the relationship between FSH and SCF in vivo is not as simple as that described in vitro. Long-term in vitro studies using co-cultures of Sertoli and germ cells (Weiss et al. 1997) or seminiferous tubule cultures (Staub et al. 2000) should shed more light on the regulation SCF production by FSH and/or other factors.

\section{Funding}

This work was supported by a grant from INSERM, INRA and Claude Bernard University Lyon 1. The authors declare that there is no conflict of interest that would prejudice their impartiality.

\section{References}

Ariyaratne HB \& Chamindrani Mendis-Handagama S 2000 Changes in the testis interstitium of Sprague Dawley rats from birth to sexual maturity. Biology of Reproduction 62 680-690.

Barbu V \& Dautry F 1989 Northern blot normalization with 28S rRNA oligonucleotide probe. Nucleic Acids Research 17 7115-7117.

Bartlett JM, Kerr JB \& Sharpe RM 1988 The selective removal of pachytene spermatocytes using methoxy acetic acid as an approach to the study in vivo of paracrine interactions in the testis. Journal of Andrology 9 31-40.

Boekelheide K, Fleming SL, Johnson KJ, Patel SR \& Schoenfeld HA 2000 Role of Sertoli cells in injury-associated testicular germ cell apoptosis. Proceedings of the Society for Experimental Biology and Medicine 225 105-115.

Chapin RE \& Lamb JC 1984 Effects of ethylene glycol monomethyl ether on various parameters of testicular function in the F344 rat. Environmental Health Perspectives 57 219-224.

Chomczynski P \& Sacchi N 1987 Single-step method of RNA isolation by acid guanidinium thiocyanate-phenol-chloroform extraction. Analytical Biochemistry 162 156-159.

Clark AM \& Griswold MD 1997 Expression of clusterin/sulfated glycoprotein-2 under conditions of heat stress in rat Sertoli cells and a mouse Sertoli cell line. Journal of Andrology 18 257-263.

Clermont Y \& Perrey B 1957 Qualitative study of the cell population of the seminiferous tubule in immature rats. American Journal of Anatomy 100 241-267.

Flanagan JG, Chan DC \& Leder P 1991 Transmembrane form of the kit ligand growth factor is determined by alternative splicing and is missing in the Sld mutant. Cell 64 1025-1035.

Foster PM, Lloyd SC \& Blackburn DM 1987 Comparison of the in vivo and in vitro testicular effects produced by methoxy-, ethoxyand N-butoxy acetic acids in the rat. Toxicology 43 17-30.

Gnessi L, Fabbri A \& Spera G 1997 Gonadal peptides as mediators of development and functional control of the testis: an integrated system with hormones and local environment. Endocrine Reviews $\mathbf{1 8}$ 541-609.
Goddard I, Bauer S, Gougeon A, Lopez F, Giannetti N, Susini C, Benahmed M \& Krantic S 2001 Somatostatin inhibits stem cell factor messenger RNA expression by Sertoli cells and stem cell factor-induced DNA synthesis in isolated seminiferous tubules. Biology of Reproduction 65 1732-1742.

Hakovirta H, Yan W, Kaleva M, Zhang F, Vanttinen K, Morris PL, Soder M, Parvinen M \& Toppari J 1999 Function of stem cell factor as a survival factor of spermatogonia and localization of messenger ribonucleic acid in the rat seminiferous epithelium. Endocrinology 140 1492-1498.

Hugly S, Roberts K \& Griswold MD 1988 Transferrin and sulfated glycoprotein-2 messenger ribonucleic acid levels in the testis and isolated Sertoli cells of hypophysectomized rats. Endocrinology 122 1390-1396.

Kierszenbaum AL 1994 Mammalian spermatogenesis in vivo and in vitro: a partnership of spermatogenic and somatic cell lineages. Endocrine Reviews 15 116-134.

van Kroonenburgh MJ, Beck JL, Vemer HM, Rolland R, Thomas CM \& Herman CJ 1986 Effects of a single injection of a new depot formulation of an LH-releasing hormone agonist on spermatogenesis in adult rats. Journal of Endocrinology 111 449-454.

Li LH, Wine RN \& Chapin RE 1996 2-Methoxyacetic acid (MAA)-induced spermatocyte apoptosis in human and rat testes: an in vitro comparison. Journal of Andrology 17 538-549.

Maguire SM, Millar MR, Sharpe RM, Gaughan J \& Saunders PT 1997 Investigation of the potential role of the germ cell complement in control of the expression of transferrin mRNA in the prepubertal and adult rat testis. Journal of Molecular Endocrinology 19 67-77.

Marret C, Avallet O, Perrard-Sapori MH \& Durand P 1998 Localization and quantitative expression of mRNAs encoding the testis-specific histone $\mathrm{TH} 2 \mathrm{~B}$, the phosphoprotein $\mathrm{p} 19$, the transition proteins 1 and 2 during pubertal development and throughout the spermatogenic cycle of the rat. Molecular Reproduction and Development 51 22-35.

Martin FH, Suggs S, Langley KE, Lu HS, Ting J, Okino KH, Morris CF, McNiece IK, Jacobsen FW, Mendiaz EA et al. 1990 Primary structure and functional expression of rat and human stem cell factor DNAs. Cell 63 203-211.

Marziali G, Lazzaro D \& Sorrentino V 1993 Binding of germ cells to mutant Sld Sertoli cells is defective and is rescued by expression of the transmembrane form of the c-kit ligand. Developmental Biology 157 182-190.

Morales C, Hugly S \& Griswold MD 1987 Stage-dependent levels of specific mRNA transcripts in Sertoli cells. Biology of Reproduction 36 $1035-1046$.

Oke BO \& Suarez-Quian CA 1993 Localization of secretory, membrane-associated and cytoskeletal proteins in rat testis using an improved immunocytochemical protocol that employs polyester wax. Biology of Reproduction 48 621-631.

Parvinen M 1982 Regulation of the seminiferous epithelium. Endocrine Reviews 3 404-417.

Pelletier G, Cusan L, Auclair C, Kelly PA, Desy L \& Labrie F 1978 Inhibition of spermatogenesis in the rat by treatment with [D-Ala6, Des-Gly-NH210] LHRH ethylamide. Endocrinology 103 641-643.

Rivier C, Rivier J \& Vale W 1979 Chronic effects of [D-Trp6,Pro9-NEt]luteinizing hormona-releasing factor on reproductive processes in the male rat. Endocrinology 105 1191-1201.

Roberts KP, Awoniyi CA, Santulli R \& Zirkin BR 1991 Regulation of Sertoli cell transferrin and sulfated glycoprotein-2 messenger ribonucleic acid levels during the restoration of spermatogenesis in the adult hypophysectomized rat. Endocrinology 129 3417-3423.

Roberts KP, Santulli R, Seiden J \& Zirkin BR 1992 The effect of testosterone withdrawal and subsequent germ cell depletion on transferrin and sulfated glycoprotein-2 messenger ribonucleic acid levels in the adult rat testis. Biology of Reproduction 47 92-96. 
Rossi P, Albanesi C, Grimaldi P \& Geremia R 1991 Expression of the mRNA for the ligand of c-kit in mouse Sertoli cells. Biochemical and Biophysical Research Communications 176 910-914.

Rossi P, Dolci S, Albanesi C, Grimaldi P, Ricca R \& Geremia R 1993 Follicle-stimulating hormone induction of steel factor (SLF) mRNA in mouse Sertoli cells and stimulation of DNA synthesis in spermatogonia by soluble SLF. Developmental Biology 155 68-74.

Sette C, Dolci S, Geremia R \& Rossi P 2000 The role of stem cell factor and of alternative c-kit gene products in the establishment, maintenance and function of germ cells. International Journal of Developmental Biology 44 599-608.

Skinner MK 1991 Cell-cell interactions in the testis. Endocrine Reviews 12 45-77.

Staub C, Hue D, Nicolle JC, Perrard-Sapori MH, Segretain D \& Durand P 2000 The whole meiotic process can occur in vitro in untransformed rat spermatogenic cells. Experimental Cell Research $26085-95$.

Tenniswood M, Wang Z, Lakins J, Morrissey C, O’Sullivan J \& Tang H 1998 Clusterin in the male reproductive tract. Journal of Andrology 19 508-516.

Vincent S, Segretain D, Nishikawa S, Nishikawa SI, Sage J, Cuzin F \& Rassoulzadegan M 1998 Stage-specific expression of the Kit receptor and its ligand $(\mathrm{KL})$ during male gametogenesis in the mouse: a Kit-KL interaction critical for meiosis. Development 125 4585-4593.

Wang ZX, Wreford NG \& De Kretser DM 1989 Determination of Sertoli cell numbers in the developing rat testis by stereological methods. International Journal of Andrology 12 58-64.
Weiss M, Vigier M, Hue D, Perrard-Sapori MH, Marret C, Avallet O \& Durand P 1997 Pre- and postmeiotic expression of male germ cell-specific genes throughout 2-week cocultures of rat germinal and Sertoli cells. Biology of Reproduction 57 68-76.

Wong P, Pineault J, Lakins J, Taillefer D, Leger J, Wang C \& Tenniswood M 1993 Genomic organization and expression of the rat TRPM-2 (clusterin) gene, a gene implicated in apoptosis. Journal of Biological Chemistry 268 5021-5031.

Wreford NG 1995 Theory and practice of stereological techniques applied to the estimation of cell number and nuclear volume in the testis. Microscopy Research and Technique 32 423-436.

Xie WQ \& Rothblum LI 1991 Rapid, small-scale RNA isolation from tissue culture cells. Biotechniques 11 324, 326-327.

Yan W, Linderborg J, Suominen J \& Toppari J 1999 Stage-specific regulation of stem cell factor gene expression in the rat seminiferous epithelium. Endocrinology 140 1499-1504.

Yan W, Suominen J \& Toppari J 2000 Stem cell factor protects germ cells from apoptosis in vitro. Journal of Cell Science 113 161-168.

Zhengwei Y, Wreford NG \& de Kretser DM 1990 A quantitative study of spermatogenesis in the developing rat testis. Biology of Reproduction 43 629-635.

Received in final form 22 March 2005

Accepted 31 March 2005

Made available online as an Accepted Preprint

12 April 2005 